\title{
The Determinants of Dual Distribution Revisited
}

\author{
Philippe Cyrenne
}

Department of Economics Working Paper Number: 2015-04

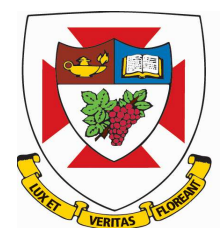

\section{UNIVERSITY OF WINNIPEG}

\author{
Department of Economics \\ 515 Portage Avenue \\ Winnipeg, Canada R3B 2E9
}

This working paper is available for download at: http://ideas.repec.org/s/win/winwop.html 


\title{
The Determinants of Dual Distribution Revisited
}

\author{
Philippe Cyrenne*
}

September 16, 2015

\begin{abstract}
This paper examines the use of what has been called dual distribution by firms. Dual distribution involves a firm using both company owned stores and independently owned franchises to sell its product or service. Using panel data from 1048 companies for the years 2005 to 2009 , I use a variety of estimators to determine the factors that influence the relative use of franchising by companies. A key focus of the paper is to control for the possible endogeneity of the franchise fee, royalty rate and franchise ratio for the companies in the respective industries. Using a panel date estimator and lagged values of the franchise fee and royalty rate as instruments, I find that one reason the franchise fee and royalty rate do not appear to influence the relative use of franchising by companies is due to industry and firm level fixed effects which capture the variation in royalty rates and franchise fees at the company level.
\end{abstract}

${ }^{*}$ Professor, Department of Economics, Faculty of Business and Economics, The University of Winnipeg, 515 Portage Avenue, Winnipeg, Manitoba, Canada. Email: p.cyrenne@uwinnipeg.ca. Phone: (204) 786-9228. I would like to thank Alan Chan for his programming assistance. I am responsible for any errors or omissions. 


\section{Introduction}

The question of why some companies use both company owned and franchise outlets to market their good and service has attracted increasing interest from economists and management scholars. The fact that firms in a number of industries use both company owned and independently owned franchises has been addressed in a growing number of theoretical and empirical papers. A key research question is what determines the use of franchise outlets versus company owned stores. This is particularly interesting since it has been observed that the extent of dual distribution, that is the extent of franchise operation, varies both between and within industries and over time. ${ }^{1}$

A related empirical issue is whether there is a predictable long run relationship between the ratio of company owned to franchised outlets used by firms. Earlier work in the management literature suggested that successful franchise systems would ultimately become wholly owned. For example, Oxenfeldt and Kelly (1968) outline a number of factors leading franchisors to buy out franchisees and why some franchisees sell good businesses. ${ }^{2}$

A number of formal explanations for dual distribution have recently emerged in the economics literature. ${ }^{3}$ The explanations are based largely on principalagent models in which the firm uses franchising as a high powered incentive when that is desired by firm owners. Models within this approach, are Gallini and Lutz (1992) and Scott (1995) where firms operate some units to signal high quality. Based on a model of asymmetric information, Gallini and Lutz (1992) show that franchisors will use both franchising and company ownership to convey information about a new product under the appropriate conditions. The reason is that both forms yield different benefits to firm owners. The benefit from franchising is that franchisees work harder than company managers since they have property rights over the stream of future profits. The benefit to company ownership is that franchisors can use company ownership to convince potential franchises about the profitability of franchise opportunities.

\footnotetext{
${ }^{1}$ In the management literature, for example Bradach (1997) and Dant et al. (2008), dual distribution is often described as a "Plural Form" of company operation, defined as the simultaneous use of company owned and franchise units.

${ }^{2}$ See Windsperger and Dant (2006), who argue in favor of the property rights approach to the franchise decision, in contrast to the agency theoretic or transaction cost theories. For a nice overview of the management literature as well as a discussion of some results from the economics literature, see Dant et al. (2008).

${ }^{3}$ The issue of dual distribution is related to the rather extensive literature on franchising. See Caves and Murphy (1976) and Mathewson and Winter (1985) for pioneering articles in this area. For overviews of the dual distribution literature see Lafontaine and Shaw (2005) and Cyrenne (2014).
} 
Thompson (1994) argues that franchising is important for facilitating rapid growth in retail markets. He provides evidence in favour of the Penrose effect, which is the argument that there are managerial limits to growth - specifically, cost increases from too rapid an increase in staff - which can be circumvented by choosing to expand by the use of franchising. ${ }^{4}$ Moreover, Thompson argues that if the Penrose effect declines over time, this may lead to some cyclical reversion to company ownership.

Bürkle and Posselt (2008) focus on the relationship between the degree of franchising and the optimal risk allocation by franchisors. Specifically, they argue the cost minimizing choice by franchisors involves the selling of franchises in order to reduce the risk from operating the company while also reducing the costs of financing the company's expansion. The risk reduction results from the substitution of part of a variable income stream to a fixed income stream it receives from franchisee-owned units. However, this risk reduction must also balance the loss of control from the reduction in the relative use of franchisor owned stores.

Recently, Cyrenne (2014) has set the dual distribution decision of a monopolist, based on the Penrose effect, in a full information model where a number of testable implications are derived. In that work, it is suggested that since the use of company owned stores and franchises are alternative methods for marketing a firm's product, it should be possible to identify conditions which would lead to a greater or lesser use of franchise operations by firms. In that model, two key parameters are the royalty rate and franchise fee, which should influence, on the margin, the relative attractiveness of franchised outlets, all else equal. Given this theoretical result, it is somewhat surprising that empirical work does not seem to support a link between royalty rates, franchise fees and the use of franchised outlets. It is this empirical question that I reexamine in this paper.

This research undertaken here makes several contributions to the literature on dual distribution. First, I also use panel data as in Lafontaine and Shaw (1999) and include industry fixed effects, however unlike Lafontaine and Shaw (1999) the model examined here focusses on the determinants of franchising. ${ }^{5}$ Second I use updated panel data on 1048 franchises over a five year period to revisit the determinants of dual distribution. Third, in examining the de-

\footnotetext{
${ }^{4}$ See Edith Penrose (1959) for a presentation of this argument. Thompson (1994:211) provides a number of reasons why franchising may allow a firm to externalize part of the management function, circumventing the Penrose constraint.

${ }^{5}$ Lafontaine and Shaw (1999) also examine the determinants of the royalty rate and franchise fee. I use similar models for the royalty rate and franchise fee in the first stage of the instrumental variable regressions.
} 
terminants of franchising, I use a GLM (Generalized Linear) model which is designed to estimate models where the dependent variable is ratio or proportion, which is the case here. Fourth, I include a number of additional variables that outline the nature of the franchising contract used by a company that have not been incorporated in previous studies. Fifth, I use an estimator to address the possible endogeneity of the average franchise fee, average royalty rate and the relative use of franchising by companies.

To briefly summarize the results, I analyze a reduced form equation for the determinants of an a firm's ratio of franchised units. I first estimate the model using OLS which can provide a useful base case which can be used for forecasting. Regarding a company's relative use of franchising (franratio), I find (i) that it is convex in the size of the company (as measured by total number of stores) and the minimum investment required by franchisees (mininvest). These results are robust to the fact that the relative use of franchising is a ratio as supported by the GLM estimates, the inclusion of industry fixed effects and whether the average royalty rate and average franchise fee is measured contemporaneously or lagged. Howver, in examining the panel data results, with lagged values of the franchise fee and royalty rate as instruments, I find that the unobserved firm heterogeneity plays a significant role, in that the Hausman test strongly supports the use of the Fixed Effect Estimator over the Random Effects Estimator. While the XTIVREG, Random Effects results mirror the OLS and and GLM results, the XTIVREG, Fixed Effects results yield little in terms of statistically significant regressors, a result of larger standard errors and the importance of firm level heterogeneity in the relative use of franchising by companies.

This paper is organized as follows. Section 2 provides an introduction to the empirical literature that examines the use of dual distribution by firms. Section 3 outlines the general empirical model while section 4 describes the data used in in the paper. Section 5 describes the estimators used while Section 6 reports the estimation results. Section 7 concludes the paper.

\section{A Brief Review of the Empirical Literature}

This paper builds on the empirical literature related to the issue of dual distribution, or what is sometimes called partial vertical integration. ${ }^{6}$ The literature

\footnotetext{
${ }^{6}$ Related to the issue of franchising is the literature that examines vertical integration and firm boundaries, for example Lafontaine and Slade (2007) and Lafontaine and Slade (2013). These papers provide a summary of studies that examine the factors that lead to
} 
is based on a number of stylized facts regarding the use of dual distribution by companies. For example, data presented by Blair and Lafontaine (2005) indicates that the extent of company owned versus franchisor owned stores varies by industry. They show that the variation in the ratio of company owned to franchised outlets varies both between industries and within industries. Industries with a high fraction of company ownership include restaurants, retailing (non-food), convenience stores. Industries with a low fraction of company owned outlets include automobile and truck dealers, educational products and services and construction, home improvement and cleaning services. ${ }^{7}$

A number of other stylized facts regarding the use of dual distribution are also of interest. Based on franchise data from 1980 to 2001, Blair and Lafontaine (2005: 67) report that the percentage of franchisors that charged royalty rates ranged from 85.7 to 91.9 over the period. The range in the mean royalty rate was 4.5 to 5.2 as a percentage of sales, with the maximum royalty rate in the 22 to $25 \%$ range. Dant et al. (2008) in comparing the franchise systems in the United States, France and Brazil report that the percentage of company owned stores is lowest in the United States (9.45\%) then Brazil $(34.68 \%)$ then France $(36.17 \%)$. The number of domestic franchised units, the average total investment, and size of the franchisee fee is significantly higher in the United States, than in France and Brazil. The age of the respective companies is highest in France, followed by the United States, then Brazil. The ongoing royalty fee is lowest in France, then the US, and then Brazil.

Earlier empirical studies examining the determinants of dual distribution include Minkler (1990), Minkler and Park (1994), Scott (1995) and Shane (1998). Minkler (1990) using data based on fast food franchise outlets in Northern California and Nevada, finds that outlets farther from the firm's headquarters tend to be franchised while older firms, having more experience in a market, tend to have more company owned outlets. Minkler and Park (1994) observe that the transaction cost approach to vertical integration predicts that as the value of the firm's brand name increases, the proportion of franchised to company-owned outlets should fall. ${ }^{8}$ The reason is that the increased brand name provides a larger incentive for franchise owners to engage in opportunistic behavior, by cutting costs and free riding on the chain's reputation. Minkler and Park (1994) find support for the transaction cost hypotheses. In particular, they find that increases in the proportion of the brand name capital expenditures, the real interest rate, and firm growth are

increased vertical integration on the part of firms.

${ }^{7}$ See Blair and Lafontaine (2005: 84-85).

${ }^{8}$ For papers that outline the transaction cost approach to vertical integration, see Klein (1980), Rubin (1978) and Mathewson and Winter (1985a). 
positively related to the increases in the degree of vertical integration, that is, company ownership. However, increases in unanticipated growth and the experience of the firm were found to be negatively related to the degree of vertical integration. ${ }^{9}$

Scott (1995) also considers the mix of franchised versus company owned outlets among franchise chains. Using a cross section of 681 firms from 1988, Scott develops an empirical model to estimate the factors that influence the proportion of franchised outlets among franchise chains. Using an OLS estimator, Scott (1995) finds that neither the royalty rate nor franchise fee affects the percentage of stores that are franchised; however, the number of years the company has been franchising, the lower capital/labour ratio, the number of states in which the franchisor has outlets increase the percentage of franchise stores, while an interaction term - the royalty rate and cash investment required - lowers the percentage. Scott (1995) concludes that his empirical results support the hypothesis that company owned outlets serve to provide an incentive for the company to maintain the quality of the system.

Using data from 1991-1994, Shane (1998) examines the effect of geographic dispersion, the royalty rate, system growth rate, system size, size of the franchise fee and initial investment on the proportion of outlets franchised in the US. Using a pooled cross-sectional approach, he finds evidence of nonlinear effects of geographic dispersion (U shaped) and firm size (inverse U shaped) on the proportion of franchised outlets in the US. A number of other hypothesis regarding the determinants of the distribution system; however, are not supported by the data.

Lafontaine and Shaw (1999) using panel data on 1,000 firms from 19801992, examine how franchisors adjust their royalty rates and franchise fees as they gain franchising experience. They find there is much persistence in the royalty rates and franchise fees used by franchisors even as they become better established. They conclude that the variation in contract terms used by franchisors is mostly determined by differences across firms.

Pénard et al. (2003) report that there is an inverse relationship between the average percentage of company owned outlets and the years of franchising experience for franchised firms in France. This is similar to Lafontaine and Shaw (2005). As the chains age, the percentage of company owned stores falls, like the US, but at a slower rate in France. Pénard et al. (2003) also report that royalty rates seem to fall slightly with years of experience but then rise significantly for older franchised firms.

\footnotetext{
${ }^{9}$ For earlier empirical work on franchising, see Minkler (1990), Lafontaine (1992), and Lafontaine and Kaufmann (1994).
} 
Dant and Kaufmann (2003) examine the changes in ownership patterns of franchised fast food restaurants as they mature. They find that while franchisors value the mix of ownership types, there is a tendency for franchisors to convert franchised outlets to company owned outlets as the franchise matures and gains greater access to resources. Using data from 745 franchisors, Pénard et al. (2003) examine the evolution of dual distribution in French franchising. They find evidence that firms target a level of company ownership, after an initial decline in the proportion of company units. They also suggest that royalty rates and company ownership are complementary variables for the organizational design of chains.

As pointed out by Lafontaine and Shaw (2005), most studies that use a cross-sectional approach find systematic evidence that the company-owned share decreases over time. Lafontaine and Shaw (2005) find, using an extensive panel data set, that experienced franchisors maintain a stable share of company owned stores over time; however, the targeted rate of company ownership varies across firms. They show that firms with valuable brand names have greater degrees of company ownership. They argue a valuable brand name provides greater incentives for firms to use company ownership in order to prevent free-riding on the firm's brand name by franchisees. ${ }^{10}$

Kosová and Lafontaine (2010) use data from franchise chains to analyze how age and the size of firms affects firm growth and survival. The data is used to examine a number of stylized facts regarding firm growth and exit that forms the basis of theoretical work on firm and industry dynamics. Using a panel data set, they find strong evidence that chains converge in size, a size which is chain specific. They also find a negative impact of the age and size of franchised retail and service chains on chain growth, consistent with previous findings.

Gillis et al. (2013) examine the proportion of units franchised by a company using what they call resource based theory. Using a survey of 168 franchisors, they test for the relative importance of two franchisor owned strategic assets - brand reputation and operating routines - and two relational strategic issues - knowledge sharing and interfirm trust - as explanations for the relative use of franchising by franchisors. They find that only relational strategic assets appear to effect franchising decisions. They acknowledge two limitations with their research, in particular, their study uses cross sectional data, and excludes

\footnotetext{
${ }^{10}$ Kalnins and Lafontaine (2004) in examining multi-unit ownership in franchising within the fast food industry in Texas find that franchisees are more likely to be allocated ownership of a new unit closer to their existing units. They also find that franchisors use similar criteria when retaining units as company owned as when choosing among franchisees.
} 
companies that are $100 \%$ franchised..$^{11}$

Finally Fan et al. (2013) examine the relationship between financial constraints and the growth of small business as represented by the growth of franchising. They study both theoretically and empirically the effect of a decline in the collateral wealth of households on franchising and find that the amount of capital required to open an outlet as well the prevailing interest rate have a negative effect on the value of franchising. This suggests that the financial constraints facing potential franchisees affects the growth of franchisors.

\section{The Model}

The empirical model used is of the general form

$$
F / T=X^{\prime} \beta+e_{t}
$$

where $F$ is the number of franchised outlets used by the company and $T$ is the total number of outlets operated by the company which includes both company owned and franchised outlets. I express the left hand side of (1) as a ratio, yielding the dependent variable franratio, which is the fraction of total outlets that are franchised. ${ }^{12}$ The variables listed in the the $X$ matrix include the average royalty rate (avgroy), the average franchise fee (avgff), the minimum investment required from a franchise operator (mininvest), the total number of outlets or units the company has (totalunits), the age of the company (age) and the number of years the company has had franchises (yearsfran), the number of states in which the company has franchises (numberstates) and whether the company has Canadian franchises (dcan). ${ }^{13}$ The reason for the use of average values is because there is often a range in royalty rates, franchise fees, and minimum investment amounts required by companies. ${ }^{14} \mathrm{I}$ also test for the possibility of nonlinear effects for totalunits, yearsfran, age and mininvest.

I also include a number of variables that describe the contract between between franchisors and franchisees. The first is the dummy variable (dconversion),

\footnotetext{
${ }^{11}$ In contrast, our data set uses a panel data set of a large number of companies and includes all franchise types.

${ }^{12}$ This is similar to the dependent variable used by Scott (1995), who used the percentage of outlets franchised.

${ }^{13}$ This also includes companies that are entirely based in Canada.

${ }^{14} \mathrm{I}$ also include the variable $d c o o p$, which is a dummy variable indicating whether the company has a cooperative advertising scheme, as an instrumental variable in the Two Stage IV estimator.
} 
which indicates whether the franchisor allows for a conversion of an existing business to a franchise operation. As discussed by Bond (2008:26-27), often franchisors seek out independent operators with limited experience since they are more likely to accept corporate direction. Bond suggests that franchisors are selective in the conversions they allow, and in many cases, the franchise fee is reduced or eliminated for conversions.

The second variable is whether a sub franchising agreement is allowed, which is captured by the dummy variable (dsubfranchising). According to Bond (2008:27), subfranchising agreements allow an investor to develop an entire area or region. The sub-franchisor becomes a self contained business responsible for all relations within its area from initial training to on-going support. According to Bond, "franchisees pay their royalties to the sub-franchisor who in turn pays a portion to the master franchisors." ${ }^{15}$ Bond suggests that sub-franchising is used primarily by smaller franchisors who are prepared to sell a portion of their future growth to someone in exchange for some frontend cash and a percentage of future royalties which they receive from their franchises.

A third dummy variable, (dearnstate) is used to indicate whether an Earnings Claim Statement is provided to potential franchisees. An Earnings Claim statement includes information on the range of sales at prospective locations, information on costs, statistical data about operations and other important financial information. In general only a small fraction of franchisors (12-15\%) of franchisors provide an earnings statement to franchisees. ${ }^{16}$ While all U.S. franchisors are required to provide prospective franchisees with a disclosure document called Uniform Franchisee Offering Circular, which includes information about the franchisor and the nature of the franchise, not all franchises choose to include earnings information (which would be included in Item 19 of the UFOC). The inclusion of a earnings claim statement one might think would effect the royalty rate and franchisee fee that franchisors could expect from potential franchisees, the question is whether this affects the number of potential independent franchises that might be interested in selling the franchisor's good or service.

Finally I use a dummy variable indicating whether a cooperative advertising scheme is in place (dcoop). A cooperative advertising scheme is a joint advertising program to promote the company's product or services usually in the franchisee's specific area. As Bond suggests "by agreeing to split part of

\footnotetext{
${ }^{15}$ Bond (2008:27).

${ }^{16}$ For a brief discussion of earnings claim statements see the article in ENTREPRENEUR website, http://www.entrepreneur.com/article/41008.
} 
the advertising costs, whether for television, radio or direct mail, the franchisor is not only supporting the franchisee, but guaranteeing itself royalties from the incremental sales. ${ }^{17}$ Bond suggests that the absence of a cooperative advertising campaign may suggest the franchisor is not fully committed to the franchise network.

Finally, I include a full set of time fixed effects and depending on the estimator, a full set of group or industry fixed effects.

\section{Data}

The data used for this study is based on the data collected by Bond's Franchise Guide for the years 2005, 2006, 2007, 2008 and 2009. ${ }^{18}$ The final data set is reduced from the original data set reported in the Franchise Guides for a number of reasons. In some cases, there was missing industry classification, missing royalty information, missing franchise fee information or missing minimum investment values. ${ }^{19}$

Table 1 outlines some summary statistics for the data set used here for $2009 .{ }^{20}$. There are observations on 776 companies for 2009, with the average fraction of franchised units used (franratio) by the companies being $87 \%$. On average, the age of the companies (age) in 2009 was 29.3 years, and had been operating franchises (yearsfran) for 23.8 years, and had outlets in 20 US states (numberstates), with $39.6 \%$ having outlets in Canada (dcan). The average number of units both company owned and franchised outlets (totalunits) was 476, with the company operating (ownedunits) 49 of those, with the remaining 427 operated as franchises. The average royalty rate (avgroy) was $5.9 \%$, the average franchise fee (avgff) was approximately $\$ 30,000$, while the minimum investment required of franchisees (mininvest) was $\$ 423,000$. For the year 2009, $28 \%$ of the companies in our sample had a cooperative advertising scheme (dcoop), 19\% allowed for subfranchising (dsubfranchising), 36\% provided earnings statements to prospective franchisees (dearnstatement), and $61 \%$ allowed for conversions of other businesses to franchise operations

\footnotetext{
${ }^{17}$ Bond (2008:28).

${ }^{18}$ Bond's Franchise data is also used by Kosová and Lafontaine (2010).

${ }^{19}$ The data set for the years 2005 and 2006 were merged with the data set from 2007-2009. In the earlier data set the number of industry classifications was larger, but it was possible to convert the industry groups from the larger set into the smaller set of groups used in 2007-2009. The Bond Franchise Guide does not have an existing time series history of all firms, the data set constructed here involved a merger of the separate years. The last year of the present format of the data was 2009.

${ }^{20} \mathrm{~A}$ description of the variables in the data set are listed in Table 3 in the Appendix.
} 
Table 1: Summary Statistics (2009)

\begin{tabular}{l|rrrrr}
\hline Variable & Obs & Mean & Std. Dev. & Min & Max \\
\hline franratio (franchised units/total) & 776 & .87 & .2291804 & 0 & 1 \\
ownedunits & 776 & 49.1 & 305.5794 & 0 & 6357 \\
totalunits & 776 & 476.6 & 1934.492 & 1 & 32158 \\
avgroy (\%) & 776 & 5.78 & 3.173187 & 0 & 35 \\
avgff (000's) & 776 & 29.887 & 29.75897 & 0 & 700 \\
mininvest (000's) & 776 & 423.628 & 2459.522 & 1 & 53000 \\
yearsfran & 776 & 21.2 & 13.2424 & 0 & 84 \\
age & 776 & 29.2 & 17.09282 & 2 & 131 \\
numberstates & 776 & 20.2 & 16.69837 & 0 & 52 \\
dcan & 776 & 0.40 & 0.489572 & 0 & 1 \\
dcooperative & 776 & 0.28 & 0.4497422 & 0 & 1 \\
dsubfranchising & 776 & 0.19 & 0.3890076 & 0 & 1 \\
dearnstatement & 776 & 0.36 & 0.4805495 & 0 & 1 \\
dconversion & 776 & 0.61 & 0.4887409 & 0 & 1 \\
\hline
\end{tabular}

Source: Bond's Franchise Guide (separate years)

(dconversion).

In terms of industry representation, the Bond Franchise Guide classifies company into 28 industry groups. From Table 2, for 2009, the largest number of franchises were in the Fast Food industry (149), followed by companies involved in Maintenance (71), the Automotive industry (55), Restaurants (48), Retail Stores (45), Services (41) and Business Related (35). It is interesting to note that all industry groups use franchising extensively, the lowest fraction of franchising is in the Publication industry .74 while the highest are in Party Related goods (1.00), Pet and Pet Related Products (.99), Travel (.98) and the Frozen Dessert group (.97).

Table 2 also shows a range the average values by industry group for a number of key regressors. For example, regarding the average royalty by industry group, the mean royalty rate ranges from a low of $2.33 \%$ for the Travel industry and a high of $9.43 \%$ for the Computer Industry group. Regarding the average franchise fee, the mean value ranges from a low of $\$ 16,433$ for the Travel group to $\$ 54,000$ for the Health and Fitness group. Finally, the mean minimum investment required of franchisees was $\$ 10,100$ for the Travel group, while the largest, as might be expected was for companies in the Lodging group, with close to $\$ 9$ million required.

For the complete data set, we have 4113 observations. This is an unbal- 
Table 2: Summary Statistics by Franchise Group (2009)- Average Values

\begin{tabular}{c|l|ccccc} 
group & Industry & $\mathrm{n}$ & franratio & avgroy $(\%)$ & avgff $(\$)$ & mininvest $(\$)$ \\
\hline 1 & Automotive Industy & 55 & 0.88 & 6.16 & 29.993 & 188.675 \\
2 & Baked Goods & 23 & 0.87 & 5.69 & 28.783 & 237.022 \\
3 & Beauty Related & 21 & 0.76 & 4.82 & 23.143 & 168.495 \\
4 & Building and Construction & 27 & 0.95 & 5.30 & 32.450 & 285.941 \\
5 & Business-Related & 35 & 0.89 & 9.12 & 33.500 & 91.129 \\
6 & Child-Related & 30 & 0.92 & 6.87 & 36.567 & 432.543 \\
7 & Clothing and Accessories & 6 & 0.86 & 4.67 & 26.167 & 173.350 \\
8 & Computer Products and Services & 7 & 0.85 & 9.43 & 29.100 & 83.371 \\
9 & Decorating and Home Design & 26 & 0.81 & 5.85 & 33.698 & 149.469 \\
10 & Education-Related & 15 & 0.87 & 8.73 & 40.867 & 130.540 \\
11 & Fast Food Restaurants & 148 & 0.85 & 5.52 & 25.474 & 315.738 \\
12 & Frozen Desserts & 18 & 0.97 & 4.80 & 27.861 & 198.822 \\
13 & Health and Fitness & 30 & 0.76 & 6.47 & 54.767 & 121.523 \\
14 & Lodging & 18 & 0.81 & 4.66 & 46.736 & 8980.167 \\
15 & Maintenance Services & 70 & 0.93 & 6.16 & 25.591 & 56.884 \\
16 & Party Related Goods and Services & 2 & 1.00 & 6.50 & 29.100 & 139.700 \\
17 & Personnel Services & 14 & 0.75 & 6.98 & 31.429 & 108.025 \\
18 & Pet Related Products and Services & 8 & 0.99 & 5.00 & 26.688 & 110.125 \\
19 & Photographic Products and Services & 8 & 0.81 & 3.81 & 26.525 & 116.625 \\
20 & Printing & 14 & 0.96 & 5.90 & 29.536 & 216.007 \\
21 & Publications & 3 & 0.66 & 5.33 & 18.583 & 30.567 \\
22 & Real Estate & 20 & 0.96 & 6.00 & 21.038 & 55.770 \\
23 & Restaurants (Sit Down) & 49 & 0.72 & 4.45 & 32.199 & 643.815 \\
24 & Retail Food & 24 & 0.85 & 5.35 & 27.523 & 169.813 \\
25 & Retail Stores & 45 & 0.87 & 5.91 & 27.788 & 149.881 \\
26 & Security-Related & 2 & 0.87 & 3.75 & 35.000 & 144.750 \\
27 & Services-General & 41 & 0.96 & 6.28 & 24.234 & 131.251 \\
28 & Sports and Recreation & 14 & 0.88 & 5.00 & 31.154 & 180.714 \\
29 & Travel & 3 & 0.98 & 2.33 & 16.433 & 10.100 \\
\hline Total & & & & & & 423.628 \\
\hline & & 0.87 & 5.91 & 29.887 & \\
\hline
\end{tabular}


anced panel based on 1048 companies over the five year period.

\section{Estimation Procedure}

A number of estimators can be used in principle to estimate the model outlined in 1 . In addition, one has to specify whether a linear or logarithmic model is appropriate. ${ }^{21}$ For the estimation problem considered here, a significant issue is that a number of companies do not have any franchised outlets, which makes the logarithmic specification problematic. ${ }^{22}$

To provide a base case for the results, I estimate equation (1) using OLS, with cluster adjusted standard errors, with the cluster variable the franchisor. Three OLS estimates are presented in Table 4. The first includes the royalty rate and franchise fee contemporaneously with industry fixed effects, the second uses lagged values of the royalty rate and franchise fee without industry fixed effects, while column (3) includes lagged values of the royalty rate and franchise fee as well as industry fixed effects.

As a check for robustness, I also estimate the model using the GLM fractional logit model developed by Papke and Wooldridge (1996). ${ }^{23}$ As discussed by Baum (2008:299), often a response variable appears as a proportion or fraction, in the case examined here, we have the fraction of total outlets of a company that are franchised. Given the nature of the dependent variable, the estimator chosen must be able to take into account the bounded nature of the response variable. As pointed out by Baum (2008), a logit estimator can be considered however it is possible that the fraction of franchised outlets used by a company is 0 or 1 , which would make the logit model inappropriate. To handle such problems, Papke and Wooldridge (1996) develop an estimator to incorporate boundary values as well as intermediate values where the dependent variable is a proportion. ${ }^{24}$ The Papke and Wooldridge approach using Stata, involves a GLM (Generalized Linear Model) fractional logit model, which features a logit transformation of the response variable and the binomial distribution, which has been suggested would be a good choice of family even

\footnotetext{
${ }^{21}$ It is well known that a Box Cox estimator can be used to determine the appropriate functional form.

${ }^{22}$ For example, if a company only uses company owned stores at the outset, this company would be dropped from the sample if a logarithmic model was used.

${ }^{23}$ A helpful overview of the GLM estimator as implemented in Stata is Baum (2008).

${ }^{24}$ As observed by Baum (2008) the Tobit model which is based on censored normal regression techniques is not an appropriate strategy since proportions variable is not censored, values outside the $[0,1]$ interval are not feasible for proportions data.
} 
if the response is continuous. ${ }^{25}$ For the GLM estimator, I also used lagged values of the average royalty rate and franchise fee.

The empirical models estimated so far assume that two key regressors, the royalty rate and franchise fee are either exogenous or predetermined. However, as outlined by Cyrenne (2014), it would appear that in deciding on the use of franchised outlets that the franchisee fee and royalty rate should play a role. For example, one might suspect that the royalty rate is a decision variable of the company, that is the royalty rate may be endogenous. Similarly, the company may have some ability to set the franchise fee. It is clear that the ability of a company to set either the royalty rate or franchise fee would depend on its market power in the market for franchise operators. In cases, where the company has little market power, the franchise fee and royalty rate may be considered exogenous.

To examine the issue of the possible endogeneity of the royalty rate and franchise fee I estimate a Two Stage Instrumental Variable Estimator. Regarding the Two Stage Instrumental Variable Estimator, it is important to outline an identification strategy. ${ }^{26}$ As observed by Angrist and Pischke (2009) finding excluded variables that can be used to identify endogenous variables in the equation of interest can be challenging. Instrumental variables must be correlated with the endogenous variable but uncorrelated with the dependent variable and hence error term in the equation of interest. To identify the royalty rate and franchise fee, I use their lagged values as instruments, which are then estimated using a Two Stage IV estimator which is implemented using Stata's XTIVREG estimator. I report fixed effects and random effects estimates using the XTIVREG estimator.

\section{Estimation Results}

To briefly summarize the results, I analyze a reduced form equation for the determinants of an a firm's ratio of franchised units with the results reported in Table 4. Regarding the OLS estimates regarding a company's relative use of franchising (franratio) which are presented in columns (1) to (3), I find that it is convex (U shaped) in the size of the company (as measured by total number

\footnotetext{
${ }^{25}$ As pointed out by Baum (2008:301), the variance of the binomial distribution must go to zero as the mean goes to either 0 or 1 , as in each case the variable is approaching a constant, and the variance will be maximized for a variable with mean of 0.5.

${ }^{26}$ See Angrist and Pischke (2009) for a discussion of this issue of identification strategies for instrumental variables in econometrics. Regarding testing for identifiability and specification in instrumental variable models see Cragg and Donald (1993).
} 
of stores), the minimum investment required by franchisees (mininvest) and the age of the company. This suggests that there is an optimal franchise ratio with respect to the size of the company, the minimum investment required by franchisees, and the age of the company, with the franchise ratio first falling and then increasing as the company gets larger, the minimum investment required increases and the company gets older. I also find that the franchise ratio is concave (inverse $U$ shaped) in the experience the company has franchising, with the franchise ratio increasing with the years franchising up to a critical number of years than the franchise ratio begins to decrease. I also find that franchisors that allow subfranchising by franchisees have a higher relative use of franchising, while those who issue earnings statement to potential franchisees have a lower relative use of franchising.

Regarding the GLM estimates (column 4), where the estimator is designed to incorporate the fact that the dependent variable (franratio) is a proportion, the results closely mirror the OLS results. Of interest is the fact that the lagged value of the franchise fee is statistically significant and positive, suggesting a higher average franchise fee received from franchisees, the greater is the relative use of franchising by companies. To summarize, the OLS results are robust to the fact that the relative use of franchising is a ratio as supported by the GLM estimates, the inclusion of industry fixed effects and whether the average royalty rate and average franchise fee is measured contemporaneously or lagged.

Regarding the panel data estimators, I estimate equation (1) using two instrumental estimators, implemented as XTIVREG in Stata. As instruments for the average franchise fee and average royalty rate, I use their lagged values. $^{27}$ While the XTIVREG, Random Effects results mirror the OLS and and GLM results, the XTIVREG, Fixed Effects yield little in terms of statistically significant regressors, a result of larger standard errors and the importance of firm level heterogeneity in the relative use of franchising by companies. I find that the unobserved firm heterogeneity plays a significant role, in that the Hausman test strongly supports the use of the Fixed Effect Estimator over the Random Effects Estimator. ${ }^{28}$

\footnotetext{
${ }^{27}$ First stage results are available on request.

${ }^{28}$ The Hausman test which tests the null that the difference in coefficients between the XTIVREGFE and XTIVREGRE are not systematic yields a chi squared statistic of chi2(16) $=192.29$, with a Prob $>$ chi $2=0.0000$. The XTIVREG results are very similar to the results using STATA's panel data estimator XTREG, with lagged values of the average royalty rate and franchise fee used as regressors. These results are available on request.
} 


\section{Conclusions}

The equilibrium framework developed in Cyrenne (2014 ), examines a number of testable implications, which include changes to the economic environment facing franchisors, as well as changes in the respective costs of company owned versus franchised outlets, the size of franchise fees, set up costs, and the royalty rate, as well as a number of other variables, on the relative use of franchising by companies. This paper has presented some empirical evidence examining the factors that determine the extent of franchising using by firms.

A central objective of this paper is to test the robustness of these results. In doing so, I considered two types of estimators, the GLM estimator of Papke and Wooldridge (1996) which is used to estimate models where the dependent variable is a proportion or fraction. This issue is relevant to the estimation problem here since my goal is to determine the factors that influence the fraction or ratio of franchised outlets used by a company. To address the potential endogeneity of the franchise fee and royalty rate, I use a Two Stage IV estimator implemented as XTIVREG in STATA.

Regarding the parameter estimates from the equation of interest, the franchise ratio, the OLS, GLM and XTIVREG Random Effects estimates are similar. They suggest the relative use of franchising is convex in the total number of units and the age of the company, concave in years franchised, and increasing in the number of states in which the company has franchises and a presence in Canada. In addition, the estimators reveal that financial entry into franchising plays a significant role, in that the higher the minimum investment required for a franchise, the lower is the relative use of franchising. However, the results for the XTIVREG Fixed Effects yield little in terms of statistically significant parameters, as a result of larger standard errors from the use of instruments, and the fact that firm and industry level heterogeneity plays a significant role in determining a company's relative use of franchising. This is supported by a Hausman test.

To conclude, in terms of reduced form results for forecasting purposes, the results obtained here mirror a number of existing results in the literature. Caution is suggested; however, given that fact that firm and industry level heterogeneity appear to play an important role in explaining the relative use of franchising and hence dual distribution by companies. 


\section{References}

[1] Angrist, Joshua D. and Jörn-Steffen Pischke Mostly Harmless Econometrics: An Empiricist's Companion, Princeton: Princeton University Press, 2009.

[2]Baum, Christopher F.(2008) "Stata tip 63: Modeling proportions" The Stata Journal 8, 2, pp. 299303.

[3] Blair, Roger D. and Francine Lafontaine The Economics of Franchising, New York: Cambridge, 2005.

[4] Bond, Robert E. Bond's Franchise Guide:19th Annual Edition, Source Book Publications: Oakland CA, 2009.

[5] Bradach, Jeffrey L. (1997) "Using the Plural Form in the Management of Restaurant Chains" Administrative Science Quarterly, 42, 2, 276-303.

[6] Bürkle, Thomas and Thorsten Posselt (2008) "Franchising as a plural system: A risk-based explanation" Journal of Retailing, 84, 39-47.

[7] Caves, R.E. and W.F. Murphy (1976) "Franchising: Firms, Markets and Intangible Assets," Southern Economic Journal, Vol. 42, 572-586.

[8] Cyrenne, Philippe (2014) "Dual Distribution and the Penrose Effect" International Journal of the Economics of Business, 21,1,55-76.

[9] Dant, Rajiv P., Rozenn Perrigot and Gérard Cliquet (2008) "A CrossCultural Comparison of the Plural Forms in Franchise Networks: United States, France and Brazil" Journal of Small Business Management, 46,2, 286311.

[10] Dant, Rajiv P. and Patrick J. Kaufmann (2003) "Structural and strategic dynamics in franchising" Journal of Retailing, 79, 63-75.

[11] Fan, Ying and Kühn, Kai-Uwe and Francine Lafontaine (2013), "Financial Constraints and Moral Hazard: The Case of Franchising" DICE Discussion Paper, No. 114.

[12] Gallini, Nancy and Nancy A. Lutz (1992) "Dual Distribution and Royalty Fees in Franchising" The Journal of Law, Economics and Organization, 8, 471-501.

[13] Gillis, William E., James G. Combs and David J. Ketchen Jr. (2013) "Using Resource-Based Theory to Help Explain Plural Form Franchising" Entrepreneurship Theory and Practice, 449-472.

[14] Kalnins, Arturs and Francine Lafontaine (2004) "Multi-unit ownership in franchising: evidence from the fast food industry in Texas" The Rand Journal of Economics, 35,4, 747-761.

[15] Klein, Benjamin (1980) "Transaction Cost Determinants of Unfair Contractual Arrangements" American Economic Review,70, 356-362. 
[16] Kosová, Renáta and Francine Lafontaine (2010) "Survival and Growth in Retail and Service Industries: Evidence from Franchised Chains" The Journal of Industrial Economics, 58, 3, 542-578.

[17] Lafontaine, Francine and Margaret E. Slade (2013) "Inter-Firm Contracts" in Robert Gibbons and John Roberts eds. The Handbook of Organizational Economics, Princeton: Princeton University Press, 2013.

[18] Lafontaine, Francine and Margaret E. Slade (2007) "Vertical Integration and Firm Boundaries: The Evidence" Journal of Economic Literature, XLV, 629-685.

[19] Lafontaine, Francine and Kathryn L. Shaw (2005) "Targeting Managerial Control: Evidence from Franchising" The RAND Journal of Economics Vol. 36, No. 1, 131-150.

[20] Lafontaine, Francine and Kathryn L. Shaw (1999) "The Dynamics of Franchise Contracting: Evidence from Panel Data" Journal of Political Economy Vol. 107, No. 5, 1041-1080.

[21] Lafontaine, Francine (1992) "Agency Theory and Franchising: Some Empirical Results" the RAND Journal of Economics, Vol. 23, No. 2, 263-283.

[22] Lafontaine, Francine and Patrick J. Kaufmann (1994) "The Evolution of Ownership Patterns in Franchise Systems" Journal of Retailing, 70, 2, 97-113. [23] Mathewson, F.G. and R.A. Winter (1985a) "The Economics of Franchise Contracts," Journal of Law and Economics, Vol. 28, pp. 503-526.

[24] Minkler, Alanson P. and Timothy A. Park (1994) "Asset Specificity and Vertical Integration in Franchising" Review of Industrial Organization, 9, 409423.

[25] Minkler, Alanson P. (1990) "An Empirical Analysis of a Firm's Decision to Franchise" Economics Letters, 34, 77-82.

[26] Oxenfeldt, Alfred R. and Anthony O. Kelly (1968) "Will Successful Franchise Systems Ultimately Become Wholly-Owned Chains?" Journal of Retailing 44(4), 69-87.

[27] Papke, L. E., and J. M. Wooldridge (1996) "Econometric methods for fractional response variables with an application to 401(K) plan participation rates" Journal of Applied Econometrics 11, 619632.

[28] Pénard, Thierry, Emmanuel Raynaud \& Stéphane Saussier (2003) "Dual

Distribution and Royalty Rates in Franchised Chains" Journal of Marketing Channels, 10:3-4, 5-31.

[29] Penrose, Edith T. The Theory of the Growth of the Firm, Oxford: Basil Blackwell, 1959.

[30] Rubin, P. (1978) "The Theory of the firm and the Structure of the Franchise Contract" Journal of Law and Economics,21, 223-233. 
[31] Scott, Frank A. Jr. (1995) "Franchising vs. Company Ownership as a Decision Variable of the Firm" Review of Industrial Organization, 10: 69-81. [32] Thompson, R. Steve (1994) "The franchised life cycle and the Penrose effect" Journal of Economic Behavior and Organization, 24: 207-218.

[33] Windsperger, Josef and Rajiv Dant (2006) "Contractibility and ownership redirection in franchising: A property rights view" Journal of Retailing, 82,3, 259-272. 
Table 3: Definitions of Variables

\begin{tabular}{l|l}
\hline franratio & Ratio of total units operated as franchises \\
ownedunits & Number of Company Owned Outlets $(\mathrm{n})$ \\
franchisedunits & Number of Franchised Outlets $(\mathrm{n})$ \\
totalunits & Number of Total Units $(\mathrm{n})$ \\
avgroy & Average Royalty charged franchisees $(\%)$ \\
avgff & Average Franchise Fee $(\$ 000 \mathrm{~s})$ \\
mininvest & Minimum Total Investment Required $(\$ 1,000 \mathrm{~s})$ \\
age & Age of Company (Franchisor) (years) \\
yearsfran & Number of years Company has been franchising (years) \\
numberstates & Number of states that Company has franchises (n) \\
dcooperative & Cooperative Advertising (Yes=1, No=0) \\
dcan & Company has Canadian franchises $(Y e s=1$, No=0) \\
dsubfranchising & Subfranchising Allowed (Yes=1, No=0) \\
dearnstatement & Earnings Statement Provided (Yes=1, No=0) \\
dconversion & Conversion to Franchise Allowed $(Y e s=1$, No=0) \\
\hline
\end{tabular}


Table 4: OLS, GLM and XTIVREG Results - Dependent Variable (Franratio)

\begin{tabular}{|c|c|c|c|c|c|c|}
\hline & $\begin{array}{l}(1) \\
\text { ols1 }\end{array}$ & $\begin{array}{l}(2) \\
\text { ols2 }\end{array}$ & $\begin{array}{c}(3) \\
\text { ols3 }\end{array}$ & $\begin{array}{c}(4) \\
\text { glm1 }\end{array}$ & $\begin{array}{c}5) \\
\text { xtivregfe }\end{array}$ & $\begin{array}{c}6) \\
\text { xtivregre }\end{array}$ \\
\hline avgroy & $\begin{array}{c}0.001659 \\
(0.424)\end{array}$ & & & & $\begin{array}{c}0.014184 \\
(0.195)\end{array}$ & $\begin{array}{c}0.003742 \\
(0.124)\end{array}$ \\
\hline avgff & $\begin{array}{c}0.000001 \\
(0.223)\end{array}$ & & & & $\begin{array}{c}0.000000 \\
(0.680)\end{array}$ & $\begin{array}{c}-0.000000 \\
(0.659)\end{array}$ \\
\hline totalunits & $\begin{array}{c}-0.000028^{* *} \\
(0.002)\end{array}$ & $\begin{array}{c}-0.000024^{* *} \\
(0.009)\end{array}$ & $\begin{array}{c}-0.000027^{* * *} \\
(0.000)\end{array}$ & $\begin{array}{c}-0.000030^{* * *} \\
(0.000)\end{array}$ & $\begin{array}{c}-0.000015 \\
(0.095)\end{array}$ & $\begin{array}{c}-0.000018^{* *} \\
(0.004)\end{array}$ \\
\hline totalunitsq & $\begin{array}{c}0.000000^{*} \\
(0.020)\end{array}$ & $\begin{array}{c}0.000000^{*} \\
(0.045)\end{array}$ & $\begin{array}{c}0.000000^{* * *} \\
(0.000)\end{array}$ & $\begin{array}{l}0.000000^{* * *} \\
\quad(0.000)\end{array}$ & $\begin{array}{c}0.000000 \\
(0.085)\end{array}$ & $\begin{array}{c}0.000000^{*} \\
(0.018)\end{array}$ \\
\hline yearsfran & $\begin{array}{c}0.017753^{* * *} \\
(0.000)\end{array}$ & $\begin{array}{c}0.015593^{* * *} \\
(0.000)\end{array}$ & $\begin{array}{c}0.015741^{* * *} \\
(0.000)\end{array}$ & $\begin{array}{c}0.011324^{* * *} \\
(0.000)\end{array}$ & $\begin{array}{c}-0.001658 \\
(0.346)\end{array}$ & $\begin{array}{c}0.008697^{* * *} \\
(0.000)\end{array}$ \\
\hline yearsfransq & $\begin{array}{c}-0.000184^{* * *} \\
(0.000)\end{array}$ & $\begin{array}{c}-0.000160^{* * *} \\
(0.000)\end{array}$ & $\begin{array}{c}-0.000157^{* * *} \\
(0.000)\end{array}$ & $\begin{array}{c}-0.000115^{* * *} \\
(0.000)\end{array}$ & $\begin{array}{c}-0.000011 \\
(0.674)\end{array}$ & $\begin{array}{c}-0.000096^{* * * *} \\
(0.000)\end{array}$ \\
\hline age & $\begin{array}{c}-0.010689^{* * *} \\
(0.000)\end{array}$ & $\begin{array}{c}-0.010438^{* * *} \\
(0.000)\end{array}$ & $\begin{array}{c}-0.010052^{* * * *} \\
(0.000)\end{array}$ & $\begin{array}{c}-0.006701^{* * *} \\
(0.000)\end{array}$ & $\begin{array}{c}-0.000418 \\
(0.733)\end{array}$ & $\begin{array}{c}-0.002963^{* *} \\
(0.003)\end{array}$ \\
\hline agesq & $\begin{array}{l}0.000079^{* * *} \\
\quad(0.001)\end{array}$ & $\begin{array}{c}0.000074^{* *} \\
(0.003)\end{array}$ & $\begin{array}{c}0.000073^{* * *} \\
(0.000)\end{array}$ & $\begin{array}{l}0.000049^{* * *} \\
(0.000)\end{array}$ & $\begin{array}{c}0.000000 \\
(0.999)\end{array}$ & $\begin{array}{c}0.000017 \\
(0.085)\end{array}$ \\
\hline numberstates & $\begin{array}{c}0.002874^{* * *} \\
(0.000)\end{array}$ & $\begin{array}{c}0.002916^{* * *} \\
(0.000)\end{array}$ & $\begin{array}{c}0.002640^{* * * *} \\
(0.000)\end{array}$ & $\begin{array}{c}0.003025^{* * *} \\
(0.000)\end{array}$ & $\begin{array}{c}-0.000389 \\
(0.438)\end{array}$ & $\begin{array}{c}0.001887^{* * *} \\
(0.000)\end{array}$ \\
\hline mininvest & $\begin{array}{c}-0.000042^{* * *} \\
(0.000)\end{array}$ & $\begin{array}{c}-0.000034^{* * *} \\
(0.000)\end{array}$ & $\begin{array}{c}-0.000038^{* * *} \\
(0.000)\end{array}$ & $\begin{array}{c}-0.000027^{* * *} \\
(0.000)\end{array}$ & $\begin{array}{c}0.000009 \\
(0.384)\end{array}$ & $\begin{array}{c}-0.000016^{* *} \\
(0.009)\end{array}$ \\
\hline mininvestsq & $\begin{array}{l}0.000000^{* *} \\
(0.009)\end{array}$ & $\begin{array}{c}0.000000^{*} \\
(0.014)\end{array}$ & $\begin{array}{c}0.000000^{* * *} \\
(0.000)\end{array}$ & $\begin{array}{c}0.000000^{*} \\
(0.049)\end{array}$ & $\begin{array}{l}-0.000000 \\
(0.275)\end{array}$ & $\begin{array}{c}0.000000 \\
(0.062)\end{array}$ \\
\hline dcan & $\begin{array}{c}0.017924 \\
(0.130)\end{array}$ & $\begin{array}{c}0.022323 \\
(0.065)\end{array}$ & $\begin{array}{c}0.017538^{*} \\
(0.033)\end{array}$ & $\begin{array}{c}0.019356^{*} \\
(0.024)\end{array}$ & $\begin{array}{c}0.002046 \\
(0.838)\end{array}$ & $\begin{array}{c}0.012884 \\
(0.136)\end{array}$ \\
\hline dcooperative & $\begin{array}{c}0.007102 \\
(0.526)\end{array}$ & $\begin{array}{c}0.004546 \\
(0.677)\end{array}$ & $\begin{array}{c}0.009389 \\
(0.235)\end{array}$ & $\begin{array}{c}0.008749 \\
(0.275)\end{array}$ & $\begin{array}{c}-0.001345 \\
(0.731)\end{array}$ & $\begin{array}{c}-0.000859 \\
(0.829)\end{array}$ \\
\hline dsubfranchising & $\begin{array}{c}0.064471^{* * *} \\
(0.000)\end{array}$ & $\begin{array}{c}0.061962^{* * *} \\
(0.000)\end{array}$ & $\begin{array}{c}0.060335^{* * *} \\
(0.000)\end{array}$ & $\begin{array}{c}0.068593^{* * *} \\
(0.000)\end{array}$ & $\begin{array}{c}-0.005832 \\
(0.704)\end{array}$ & $\begin{array}{c}0.034662^{* *} \\
(0.003)\end{array}$ \\
\hline dearnstatement & $\begin{array}{c}-0.023482^{*} \\
(0.042)\end{array}$ & $\begin{array}{c}-0.027324^{*} \\
(0.038)\end{array}$ & $\begin{array}{c}-0.023425^{* *} \\
(0.002)\end{array}$ & $\begin{array}{c}-0.023544^{* *} \\
(0.001)\end{array}$ & $\begin{array}{c}-0.006568 \\
(0.524)\end{array}$ & $\begin{array}{c}-0.015007 \\
(0.065)\end{array}$ \\
\hline dconversion & $\begin{array}{l}-0.011627 \\
(0.359)\end{array}$ & $\begin{array}{c}-0.016535 \\
(0.201)\end{array}$ & $\begin{array}{c}-0.017120^{*} \\
(0.027)\end{array}$ & $\begin{array}{c}-0.014403 \\
(0.055)\end{array}$ & $\begin{array}{c}-0.030076^{*} \\
(0.025)\end{array}$ & $\begin{array}{l}-0.010134 \\
(0.307)\end{array}$ \\
\hline i.group & included & & included & included & & included \\
\hline year 2005 & $\begin{array}{c}-0.012613 \\
(0.164)\end{array}$ & & & & & \\
\hline year2006 & $\begin{array}{c}-0.010987 \\
(0.211)\end{array}$ & $\begin{array}{c}-0.007714 \\
(0.375)\end{array}$ & $\begin{array}{c}-0.009815 \\
(0.342)\end{array}$ & $\begin{array}{c}-0.011349 \\
(0.268)\end{array}$ & $\begin{array}{c}-0.010265^{*} \\
(0.024)\end{array}$ & $\begin{array}{c}0.003548 \\
(0.350)\end{array}$ \\
\hline year 2007 & $\begin{array}{c}-0.012205 \\
(0.122)\end{array}$ & $\begin{array}{c}-0.001905 \\
(0.825)\end{array}$ & $\begin{array}{c}-0.004891 \\
(0.642)\end{array}$ & $\begin{array}{c}-0.006221 \\
(0.558)\end{array}$ & $\begin{array}{c}-0.006296 \\
(0.108)\end{array}$ & $\begin{array}{c}0.002530 \\
(0.484)\end{array}$ \\
\hline year 2008 & $\begin{array}{c}-0.010466^{*} \\
(0.029)\end{array}$ & $\begin{array}{c}-0.006067 \\
(0.273)\end{array}$ & $\begin{array}{c}-0.005607 \\
(0.574)\end{array}$ & $\begin{array}{c}-0.006069 \\
(0.535)\end{array}$ & $\begin{array}{c}-0.008087^{* * *} \\
(0.008)\end{array}$ & $\begin{array}{c}-0.003648 \\
(0.231)\end{array}$ \\
\hline L.avgroy & & $\begin{array}{c}0.001747 \\
(0.406)\end{array}$ & $\begin{array}{c}0.001314 \\
(0.322)\end{array}$ & $\begin{array}{c}0.002326 \\
(0.239)\end{array}$ & & \\
\hline L.avgff & & $\begin{array}{c}0.000003^{* * *} \\
(0.001)\end{array}$ & $\begin{array}{c}0.000002 \\
(0.503)\end{array}$ & $\begin{array}{l}0.000002^{* *} \\
(0.001)\end{array}$ & & \\
\hline _cons & $\begin{array}{c}0.757624^{* * *} \\
(0.000)\end{array}$ & $\begin{array}{c}0.805379^{* * *} \\
(0.000)\end{array}$ & $\begin{array}{c}0.784178^{* * *} \\
(0.000)\end{array}$ & & $\begin{array}{c}0.875715^{* * * *} \\
(0.000)\end{array}$ & $\begin{array}{c}0.735611^{* * *} \\
(0.000)\end{array}$ \\
\hline $\mathrm{N}$ & 4113 & 3100 & 3100 & 3100 & 3085 & 3085 \\
\hline $\mathrm{N}$ (firms) & 1048 & 1000 & 1000 & 1000 & 997 & 997 \\
\hline 11 & 739.587725 & 570.559022 & 683.425474 & & & \\
\hline r2 & 0.253822 & 0.182329 & 0.239754 & & & \\
\hline $\begin{array}{l}\text { sigma_u } \\
\text { sigma_e }\end{array}$ & & & & & $\begin{array}{l}0.257160 \\
0.054097\end{array}$ & $\begin{array}{l}0.191812 \\
0.054480\end{array}$ \\
\hline rho & & & & & 0.957623 & 0.925350 \\
\hline
\end{tabular}

